\title{
Toward a typology of incubators based on HRM
}

\author{
Chaffik Bakkali, Karim Messeghem and Sylvie Sammut ${ }^{*}$
}

\author{
*Correspondence: sylvie.sammut@ \\ univ-montp1.fr \\ Montpellier Research in \\ Management Laboratory, Labex \\ Entreprendre, Montpellier University \\ UFR AES - Avenue Raymond \\ Dugrand, Montpellier, Cedex 2, \\ CS 59640 - 34960, France
}

\begin{abstract}
The fact that there are major differences between one incubator and another has resulted in many authors working on multiple typologies. Although these typologies are relatively common in the literature, they all tend to use the same classification criteria (objectives of the structures, funding, etc.). In this article, we hope to broaden the viewpoint to human resource management (HRM) within incubators. We defend the theory that the differences between incubators are not only found at the level of their objectives or their funding, but also at the level of their HRM policies. Through conceptual reflection, we thus propose HR management that is specific to each type of structure, based on Pichault and Nizet's configurational approach (2000), as well as on Mahé de Boislandelle's social mix (1993).
\end{abstract}

Keywords: Business incubators; Typology; HRM

\section{Background}

The issue of the performance of support structures is at the heart of political and economic concerns. Governmental measures today are based on rationalization of the means allocated to support new companies. However, incubators are still characterized by wide variety and considerable disparity in terms of performance. This is why in the literature there are many definitions of what exactly an incubator is. For example, we can cite Carayannis and Von Zedtwitz (2005), who define incubators as structures that propose five types of service: access to physical resources, secretarial services, access to financial resources, assistance with start-up procedures, and access to networks. For those authors, depending on the number of services proposed, a support structure can be considered to be an incubator in either the strictest or the loosest sense of the term or even not as an incubator at all: 'Some incubators offer all five of these services: these are incubators in the strong sense of the term. Organizations that offer only four services are considered incubators in the weak sense of the term. Organizations that offer fewer than four of these services lack too many elements of incubation and should no longer be called incubators' (Carayannis and Von Zedtwitz 2005, p. 105).

This definition, which is based on the number of services proposed, is only one of the many. There are a great many others, based on other criteria: the objectives of the incubator, public or private funding, target public, etc. However, incubators have not yet been approached in the literature from the point of view of human resource management. Incubators, like all types of organization, must deal with the management of their human resources. How should such resources be managed? Is it not necessary to adapt HR management practices to the type of structure involved?

(C) 2014 Bakkali et al.; licensee Springer. This is an Open Access article distributed under the terms of the Creative Commons Attribution License (http://creativecommons.org/licenses/by/2.0), which permits unrestricted use, distribution, and reproduction in any medium, provided the original work is properly cited. 
The aim of this paper is to propose a differentiation of HR management practices in relation to the type of incubator. We will use as our basis the theory of configurations that focuses on fit between organizational characteristics and managerial practices. This conceptual reflection will combine two research fields that are not generally combined: human resource management (HRM) and entrepreneurship (Barrett and Mayson 2008).

In the Section 'Diversity in business incubators', we will focus on the diversity that can be found in business incubators. In the Section 'Differentiation in HR management within business incubators', we will try to define the HR management modes specific to each type of incubator, in the form of proposals.

\section{Results and discussion}

\section{Diversity in business incubators}

Not all incubators are identical. They have a wide range of different objectives and characteristics. These differences can be identified in the literature by means of a number of typologies.

\section{Diversity in incubators: a typological approach}

As pointed out by Aaboen (2009), there are differences between incubators in terms of the objectives they have and the types of organization they retain. Because of these differences, starting up a business is characterized by a wide range of support structures. Although sometimes this diversity is accused of hindering the support by reducing its visibility for the business creator, the study by Boter and Lundström (2005) shows that the opposite is in fact true: despite the large number of assistance structures, people with projects manage to find the structure best suited to their needs.

According to Grimaldi and Grandi (2005), this variety can be explained by the desire of incubators to adapt to the diversity found in the needs of new businesses. Moreover, just as companies adopt different business models, incubators do the same, developing a wide variety of incubating models. More specifically, there are two incubating models: one aims to support small business creation projects by reducing start-up costs, while the other aims to support ambitious business creation projects by speeding up the start-up process. This difference plays a part in reinforcing the diversity found in the key players in business support.

This diversity is taken into account in the literature through the proposal of different typologies. Although we are by no means being exhaustive, in this paper we can present some of the most commonly found typologies in the literature. The first typology identifies five types of incubators: regional incubators, university incubators, virtual incubators, independent commercial incubators, and internal business incubators. This typology is often quoted in the literature as being used as the basis for several works (Carayannis and Von Zedtwitz 2005; von Zedtwitz 2003; von Zedtwitz and Grimaldi 2006). It was established on the basis of the strategic objectives of incubators. The first two are not generally aiming to make a profit. Their focus is more on economic and technological development. As for virtual incubators, they are more focused on the Internet and ICT sectors, with the aim of making large profits but with a reasonably high risk factor. On the other hand, although independent commercial incubators and internal business incubators also hope to make a large profit, these last two generally have a lower risk factor. 
Grimaldi and Grandi (2005) propose a typology that is also based on the objectives of incubators, but which also includes a historic aspect. In this way, the centers of innovation were the first to appear, in the 1980s. They were generally created by public institutions hoping to encourage economic development. This involved promoting entrepreneurship, as well as reducing the rate of failure of young companies. To do so, centers of innovation proposed a certain number of services, such as infrastructures and technical and managerial consultancy. The next to appear were university incubators, when the public authorities understood that economic development also needed closer relations between the world of science and the world of business. In relation to the centers of innovation, the university incubators were more focused on technology transfer from universities to businesses. At the end of the 1990s, existing incubator structures were brought into question with regard to their actual efficacy. In addition, the technological revolution that started with the emergence of the Internet and information technology brought about a change in the incubation model with, among other things, a need for quick access to the market and capital. Both these elements made it possible for a final category of structure to emerge: private sector incubators. Unlike the types of incubator mentioned above, this new type was profit-based. This meant that either their services were billed or that a fraction of the profits made by the incubated firms was paid to the incubator. Private incubators can also be divided into two types: private business incubators and private independent incubators. The former were created by large companies with the aim of promoting intrapreneurship and spin-offs. The latter were launched either by an individual, or by a group, hoping to help and invest in young businesses.

Aernoudt (2004) also retained a historical approach, identifying several types of incubator. According to him, mixed incubators were the first to appear in the 1950s. These incubators offered businesses different types of service, regardless of their sector of activity: traditional, high tech, service industry.... Then, two new types of incubator developed: economic development incubators in the 1980s and technological incubators in the 1990s. The former focused on reducing disparity between the various regions, while the latter were more oriented toward technological innovation. Aernoudt (2004) also highlighted the very recent emergence of two new types of incubator. The first, the social incubator, aims to encourage the development of projects with a highly social dimension, such as those aiming to integrate certain population categories, and preserve the environment. The second type corresponds to fundamental research incubators. As their name indicates, their primary aim is to make possible the promotion of research projects from fundamental science fields, even though this is not always easy.

Albert et al. (2003) propose a typology of incubators based on several criteria: the final aim (for profit or not), the dominant activities of the projects (general or high tech), and aims (economic development, promotion of technology, etc.). These different criteria allow the authors to identify four types of structure: economic development incubators, academic and scientific incubators, business incubators, and private investment incubators. Without going into the details of all the criteria, let us simply note that the first two types of structure are not for profit, contrary to the last two. We should also note that only economic development incubators support general projects, while the other three specialize in high tech projects. 
The typologies cited clearly show that there is divergence regarding the different types of incubator. Nevertheless, these typologies tend to be based on relatively similar classification criteria. Table 1 summarizes the main typologies of incubators that can be found.

\section{Critical approach to the typologies of incubators}

'Attempts have been made to classify incubator types. This is not as easy as it sounds, however, inasmuch as no two incubators are exactly alike. Although the general goal of incubators is to develop firms and stimulate entrepreneurship, different incubators have different priorities' (Bøllingtoft and Ulhøi 2005, p. 270). This is why the literature on incubators is marked by such a large number of different typologies.

However, in our opinion, these typologies suffer from two main limitations. The first comes from the fact that the typologies do not all use the same definition for an incubator (Böhringer 2006). As pointed out by Aernoudt (2004), the definition of what an incubator is varies from one country to another. As a result, caution is required when using typologies and it is necessary to verify that the typology corresponds to the context of the study.

Let us take France as an example. In our opinion, there are no typologies that are perfectly suited to this context. We can explain this by the fact that a few typologies have been elaborated solely on the basis of the French context. Some are the result of comparisons between several countries. This is the case, for example, in the typology set out by Albert et al. (2003), which developed from a comparison of four countries: the United States, Great Britain, Germany, and France. Even though this typology obviously comes close to the French context, it is still not totally adapted. Two of the four types of incubators (business incubators and private investment incubators, to be

Table 1 Typologies of incubators

\begin{tabular}{|c|c|c|}
\hline Authors & Classification criteria & Typologies \\
\hline Carayannis and Von Zedtwitz (2005) & The strategic aims of incubators & Regional incubators \\
\hline von Zedtwitz and Grimaldi (2006) & & University incubators \\
\hline \multirow[t]{3}{*}{ von Zedtwitz (2003) } & & Virtual incubators \\
\hline & & Independent commercial incubators \\
\hline & & Incubators internal to businesses \\
\hline \multirow[t]{4}{*}{ Grimaldi and Grandi (2005) } & \multirow{4}{*}{$\begin{array}{l}\text { Objectives of incubators, } \\
\text { with a historical dimension }\end{array}$} & Centers of innovation \\
\hline & & University incubators \\
\hline & & Private business incubators \\
\hline & & Private independent incubators \\
\hline \multirow[t]{5}{*}{ Aernoudt (2004) } & \multirow{5}{*}{$\begin{array}{l}\text { Objectives of incubators, with a } \\
\text { historical dimension }\end{array}$} & Mixed incubators \\
\hline & & Economic development incubators \\
\hline & & Technological incubators \\
\hline & & Social incubators \\
\hline & & Fundamental research incubators \\
\hline \multirow[t]{4}{*}{ Albert et al. (2003) } & \multirow{4}{*}{$\begin{array}{l}\text { Multi-criteria: finality pursued, } \\
\text { dominant activities in the } \\
\text { projects, objectives, etc. }\end{array}$} & Economic development incubators \\
\hline & & Academic and scientific incubators \\
\hline & & Business incubators \\
\hline & & Private investment incubators \\
\hline
\end{tabular}


specific) are, in fact, relatively underdeveloped in France. They are more common in the United States, where they represent a significant number of the incubators operating in the country. It thus appears justified that we raise questions regarding the pertinence of retaining these two types of incubator in the French context.

The second limitation lies in the criteria retained for establishing the typologies of the structures. They are very similar to each other and have little diversity. Hackett and Dilts (2004), in the literature review that they did on incubators, identify four classification criteria used in the typologies: the nature of the businesses supported (spin-offs, start-ups...), the activity of these companies, the activity of the incubator (economic development, profit...), and the incubator's main source of funding. Recent typologies also tend to focus exclusively on the last two criteria. This is the case of most of the typologies that we have already mentioned (Aernoudt 2004; Albert et al. 2003; Carayannis and Von Zedtwitz 2005; Grimaldi and Grandi 2005; von Zedtwitz 2003; von Zedtwitz and Grimaldi 2006).

In our opinion, both these criteria, although important, have been given too significant a role to play in existing typologies as they result in other equally pertinent criteria being sidelined. The criterion focusing on the means of funding for incubators is the one that tends to be used the most. Certain works are based solely on the distinction between public and private funding. As an example, we can cite Cooke et al. (2006) who, in their work, classify the services proposed by the incubators by identifying three types of structure: public sector, private sector, and mixed sector.

Greater understanding of how incubators operate nevertheless means multiplying the points of view. This is one of the reasons why the report by Ernst and Young (2003) on incubators is based on three different typologies. The first focuses on the position of incubators in the chain of promotion/creation. The result is three types of incubator, depending on the orientation retained: promotion of technology, local development, or mixed. The second classification takes into account the sector of activity of the businesses being supported, with, once again, three types of structure: general, multi-sector, or specialized. Finally, the third typology is the result of evaluations of incubators. This evaluation made it possible to identify three incubator profiles, depending on the state of their performance indicators: 'homogenous profile', 'plan of action profile', or 'dilemma profile'. Thus, Ernst and Young (2003) opened the way for greater diversity in the typologies of incubators. We believe that it is necessary to continue in this vein, by adopting new classification criteria: 'meaningful classifications may be created by focusing on items such as the competencies of the incubator, the incubator's level of development, and the incubatees' level of potential. Theoretically grounded and tested typologies that use these metrics have the potential to be much more useful for future research than extant taxonomies' (Hackett and Dilts 2004, p. 71).

The work of the European Commission (CSES 2002) moves in this direction, classifying incubators in a matrix composed of two axes: the level of assistance provided and the level of technological specialization. This matrix then makes it possible to highlight nine types of incubators. By stating that the knowledge required is not the same for all business incubators, Becker and Gassmann (2006) are even more in line with the idea originally developed by Hackett and Dilts (2004). Becker and Gassmann (2006) effectively propose a classification for business incubators based on the type of knowledge required: entrepreneurial knowledge, organizational knowledge, technological knowledge, and additional knowledge of the market. We would like to continue in this vein, 
proposing a typology for incubators that is based on criteria that are more oriented toward human resource management.

\section{Differentiation in HR management within business incubators}

In this second section, we will be highlighting the differences that can be found from one business incubator to another in terms of HRM. To do this, we will make use of two types of work: the configurational approach by Pichault and Nizet (2000) and Mahé de Boislandelle (1993) social mix.

\section{A configurational approach within incubators}

We believe that beyond the type of structure, organization mode can be associated with HRM practices.Pichault and Nizet (2000) defend this hypothesis by retaining a configurational and contextual approach in the Pettigrew (1987) sense of the terms. The following insert summarizes the five models of HRM that appear within specific organizational configurations.

Insert 1 - Pichault and Nizet's contextual model (2000)

The arbitrary model. Informality predominates and it is the director who takes on the main areas of HRM alone. For example, staff assessments are done intuitively and communication is centralized and thus very informal. The corporate culture is characterized by the culture of the house. This type of HRM model is found above all in SMEs. The corresponding organizational configuration is entrepreneurial.

The objectivizing model. Pichault and Nizet define this as an 'attempt to systematize the various dimensions characteristic of human resource management' (p. 119). These are the impersonal criteria that govern social relations. They apply uniformly to most of the members of the organization. For example, staff assessments are based on a description of functions with application of uniform criteria. Applying rules and respecting hierarchical authority are what is most appreciated. The corresponding organizational configuration is that of mechanistic bureaucracy.

The individualizing model. Personalization of the link with employees is the key to this and the criteria are negotiated in the context of interpersonal agreements between the hierarchical lines and operators. The concept of competence is the pivot in HRM, with 'made-to-measure' training a key element in the management of skills, the aim of which is to fortify the employability of each employee. The corresponding organizational configuration is the adhocracy.

The conventionalist model. The members of the organization are qualified and master the various aspects of HRM in an informal manner. Nevertheless, they are collectively in agreement with regard to the need to define the framework and modalities for their existence. Formal standards are accepted on a temporary basis and are the result of debates, votes or elections. The corresponding organizational configuration is the professional bureaucracy.

The value-related model. The HRM is founded on giving of oneself, with constant reference to the values that are the foundation of the organization. It is thus a common project that dominates and that is the factor for identification. For example, the role of training is to allow trainees to acquire common values. The corresponding organizational configuration is missionary.

Source: Messeghem and Pierson (2003). 
These five contextual models show the existence of variations within HRM depending on the organizational configuration. Pichault and Nizet (2000) suggest grouping together the practical differences in HRM between the five models on the basis of three elements: the level of formalization of the criteria adopted for HRM practices, their degree of flexibility and their degree of either centralization or decentralization. Using these three points as the basis, it is possible to show the differences between the various types of incubator through the differences in HRM practices. By taking the Pichault and Nizet (2000) model as our inspiration, we propose associating each of these organization configurations with the business focus of the incubates (Table 2).

Missionary structures generally support social projects. This type of structure defends values, beliefs, and ideologies based on social well-being, which does not exclude the search for the creation of value. Missionary structures must therefore employ people who share this ideology. Their commitment can be seen as a gift of self. HRM based on values will therefore by the surest way, as it will make it possible to federate the employees.

Entrepreneurial structures are very often specialized in a given sector of activity, particularly through their small size and poor amount of resources. They are focused on their director, who can also be their founder. The small size of these organizations also means that the directors take on the role of direction and support. Their vision of business assistance will determine which methods are retained by other employees that have been trained. The means of operation is very informal. HRM practices are developed little and tend to be limited to simple management of personnel.

At the opposite end of the spectrum to entrepreneurial structures are mechanistic structures, which are larger in size and have a sufficient amount of resources. In this type of incubator, standards play a preponderant role. They set the framework for operations and reduce creative capacity in terms of support. Reporting systems (such as reporting for a chamber of commerce or professions to its regional chamber) tend to standardize the internal incubation process. HRM will be very formalized and based on impersonal rules.

Professional structures are developed within an academic environment. They aim to promote on the market the discoveries made by researchers. The university culture dominates. Employees must understand the standards and values of professional

Table 2 HR management practices and incubators

\begin{tabular}{llllll}
\hline & $\begin{array}{l}\text { Missionary } \\
\text { structures }\end{array}$ & $\begin{array}{l}\text { Entrepreneurial } \\
\text { structures }\end{array}$ & $\begin{array}{l}\text { Bureaucratic } \\
\text { structures }\end{array}$ & $\begin{array}{l}\text { Professional } \\
\text { structures }\end{array}$ & $\begin{array}{l}\text { Adhocratic } \\
\text { structures }\end{array}$ \\
\hline Projects supported & Social & $\begin{array}{l}\text { Specialized in a } \\
\text { single sector } \\
\text { of activity }\end{array}$ & $\begin{array}{l}\text { Several sectors } \\
\text { of activity }\end{array}$ & Academic & Technological \\
HR management & $\begin{array}{l}\text { Value-related } \\
\text { model }\end{array}$ & Arbitrary model & $\begin{array}{l}\text { Objectivizing } \\
\text { model }\end{array}$ & $\begin{array}{l}\text { Conventionalist } \\
\text { model }\end{array}$ & $\begin{array}{l}\text { Individualizing } \\
\text { model }\end{array}$ \\
Criteria adopted & $\begin{array}{l}\text { implicit } \\
\text { (reference } \\
\text { to values) }\end{array}$ & Nonexistent & Formalized & Formalized & Formalized in an \\
Formalization & Low & Low & following debate & interpersonal \\
context
\end{tabular}

Adapted from Pichault and Nizet (2000). 
organizations, while also satisfying the entrepreneurial issues associated with promoting opportunities. HRM practices are developed in a collegial manner.

Adhocratic structures propose support to business creators who develop innovative projects with a strong technological content. They must propose a framework that makes it possible to stimulate innovation. The employees combine technological and economic expertise. These structures put the emphasis on individualizing management 'focusing on personalizing ties between employees' (Pichault and Nizet 2000, p. 128).

By cross-referencing incubators and HRM practices, it is possible to make a proposition that nevertheless needs to be validated. We will now propose a means of going even further, by studying the differences between incubators in the main fields of HRM (hiring, training, etc.).

\section{HRM practices in incubators}

As a means of explaining how incubators work, Aaboen (2009) proposes an analogy with service industries for professionals. These firms deal with the customer relations management process through qualified personnel composed of workers with knowledge. Completing their missions supposes management of human resources. To analyze this human resource management within incubators, we propose an analogy with small and medium enterprises (SMEs). We can justify this analogy through several elements.

First, the resemblance in terms of size seems clear. Like the SMEs that they support, business incubators are often small in size. As a result, just like SMEs, the human resources function is not necessarily materialized through an HR department (Mahé de Boislandelle 1993). HRM thus cannot be approached in the same way as in a large company, which generally has specialized employees performing these tasks. So, for a more detailed analysis of the HRM practices of incubators, we can use as our basis the model developed by Mahé de Boislandelle (1993) for SMEs. This systemic model leads to four axes: employment, pay, promotion, and participation:

1. The employment policy refers essentially to the hiring of employees. This is not an easy task and incubators can be confronted with a high turnover rate. Should the focus be placed on hiring project managers who already have entrepreneurial experience? Or should it be on hiring those with functional or technological expertise? The personnel responsible for supporting projects can combine a high level of education with entrepreneurial experience. This profile may play a part in reinforcing the credibility of the assistance in the eyes of the person with the project (Aaboen 2009).

2. The pay policy can be seen from the point of view of a reward or incentive system. Incubators do not always have the means to implement an adapted pay policy to gain the loyalty of their employees. The structures are very often not for profit and rely on funding in the form of subsidies, the long-term availability of which is not guaranteed. Call for tender logic may encourage short-term logic in terms of pay policies.

3. The promotion policy 'covers all the actions, deliberate or accepted by the company, designed to enrich the life of each employee in terms of knowledge, know-how, material and psychological comfort in the workplace, status and social recognition' (Mahé de Boislandelle 1993, p. 115). Skill management is one of the 
key aspects of the promotion policy. Developing skills is essential, particularly in order to face up to changes associated with the institutional framework of business creation. In the last few years, business creation has changed considerably, as in France for example, with the adoption of the auto-entrepreneur status or the implementation of the system 'Nouvel Accompagnement pour la Création et la Reprise d'Entreprise' (new support for the creation and takeover of businesses, NACRE). As a result, training and certification of employees is an effective means for incubators to face up to these changes. Organizations such as APCE (agency for the creation of businesses) in France play a part in training employees through seminars and online tools.

4. The participation policy is 'the superior form of promoting employees within an organization.' For Mahé de Boislandelle (1993), this refers in particular to management style, which can be one of four different forms:

(a) The directive style: the emphasis is placed on respecting instructions

(b)The persuasive style: consists in explaining decisions and giving encouragement

(c) The participative style: based on agreement

(d)The delegative style: accompanied by decentralization

The proximity between the director of the incubator and the employees can make it easier to associate them with the decision-making process. The nature of the activity can lead to power being delegated to project managers with considerable experience. The participative and delegative styles will thus find promising ground. As a result of the diversity found in incubators, we defend the idea that the four axes in the social mix do not take the same form from one type of structure to another (Table 3).

\section{Conclusions}

Several authors have shown interest in classifying incubators by developing diverse typologies. However, the fact remains that most typologies are based on relatively similar classification criteria. As a result, the typologies are often poorly differentiated. It thus seems necessary to diversify the classification criteria further so as to improve our understanding of incubators.

The main result of this research is that we propose a typology for incubators that associates the aims and practices of HRM. Few works have focused on how HR

Table 3 Social mix and incubators

\begin{tabular}{|c|c|c|c|c|c|}
\hline & $\begin{array}{l}\text { Bureaucratic } \\
\text { structure }\end{array}$ & $\begin{array}{l}\text { Professional } \\
\text { structure }\end{array}$ & $\begin{array}{l}\text { Adhocratic } \\
\text { structure }\end{array}$ & $\begin{array}{l}\text { Entrepreneurial } \\
\text { structure }\end{array}$ & $\begin{array}{l}\text { Missionary } \\
\text { structure }\end{array}$ \\
\hline $\begin{array}{l}\text { Employment } \\
\text { axis }\end{array}$ & General hiring & $\begin{array}{l}\text { Hiring scientists } \\
\text { with entrepreneurial } \\
\text { experience }\end{array}$ & $\begin{array}{l}\text { Hiring scientists } \\
\text { with entrepreneurial } \\
\text { experience }\end{array}$ & $\begin{array}{l}\text { Hiring specialists } \\
\text { in a given sector }\end{array}$ & $\begin{array}{l}\text { Hiring generalists } \\
\text { with experience } \\
\text { in social } \\
\text { entrepreneurship }\end{array}$ \\
\hline $\begin{array}{l}\text { Promotion } \\
\text { axis }\end{array}$ & $\begin{array}{l}\text { Institutionalized } \\
\text { training }\end{array}$ & $\begin{array}{l}\text { Training at the } \\
\text { hands of } \\
\text { professionals }\end{array}$ & $\begin{array}{l}\text { Training focused } \\
\text { on well-being }\end{array}$ & $\begin{array}{l}\text { Little training, } \\
\text { knowledge hand } \\
\text { down to future } \\
\text { 'generations' }\end{array}$ & $\begin{array}{l}\text { Little } \\
\text { institutionalized } \\
\text { training, } \\
\text { socialization }\end{array}$ \\
\hline Pay axis & $\begin{array}{l}\text { Salary } \\
\text { determined } \\
\text { a priori }\end{array}$ & $\begin{array}{l}\text { Salary determined } \\
\text { a priori }\end{array}$ & $\begin{array}{l}\text { Based on the } \\
\text { number of start-up } \\
\text { creations }\end{array}$ & No pay policy & $\begin{array}{l}\text { Question seen } \\
\text { to have little } \\
\text { legitimacy }\end{array}$ \\
\hline $\begin{array}{l}\text { Participation } \\
\text { axis }\end{array}$ & $\begin{array}{l}\text { Directive } \\
\text { management }\end{array}$ & $\begin{array}{l}\text { Management } \\
\text { by delegation }\end{array}$ & $\begin{array}{l}\text { Management } \\
\text { by delegation }\end{array}$ & $\begin{array}{l}\text { Participatory } \\
\text { management }\end{array}$ & $\begin{array}{l}\text { Persuasive } \\
\text { management }\end{array}$ \\
\hline
\end{tabular}


management is organized within incubators. Yet, the performances of these structures are based essentially on the quality of the support provided by their employees. These organizations must therefore develop real HRM policies. Our analysis shows that these policies will differ from one type of incubator to another. As a result, in the aim of characterizing incubators, we have used two reading keys. First, we used Pichault and Nizet's configurational approach (2000), which allowed us to show the differences between incubators in terms of the formalization, flexibility and decentralization of HRM practices. Then, making an analogy between incubators and SMEs allowed us to study the differences in four key HRM areas: employment, promotion, pay, and participation (Mahé de Boislandelle 1993).

It should be specified that this paper is a conceptual reflection that has made it possible to make propositions. These propositions still need to be the subject of validation through an empirical study. From a managerial point of view, this research should make it possible for the managers of incubators to ask themselves questions concerning the relevance of their HRM practices.

Competing interests

The authors declare that they have no competing interests.

\section{Authors' contributions}

All the authors have contributed on the whole paper. All authors read and approved the final manuscript.

Received: 23 September 2013 Accepted: 4 October 2013

Published: 14 Jan 2014

\section{References}

Aaboen, L. (2009). Explaining incubators using firm analogy. Technovation, 29(10), 657-670.

Aernoudt, R. (2004). Incubators: tool for entrepreneurship? Small Business Economics, 23(2), 127-135.

Albert, P, Bernasconi, M, \& Gaynor, G. (2003). Incubateurs et pépinières d'entreprises: un panorama international. Paris: L'Harmattan.

Barrett, R, \& Mayson, S. (2008). International handbook of entrepreneurship. Cheltenham: Edward Elgar.

Becker, B, \& Gassmann, O. (2006). Gaining leverage effects from knowledge modes within corporate incubators. R\&D Management, 36(1), 1-16.

Böhringer, A. (2006). Knowledge specialization and transfer: a knowledge based framework for business incubation. Copenhagen: DRUID Summer Conference. June 18-20, 2006.

Bøllingtoft, A, \& Ulhøi, JP. (2005). The networked business incubator - leveraging entrepreneurial agency? Journal of Business Venturing, 20(2), 265-290.

Boter, H, \& Lundström, A. (2005). SME perspectives on business support services: the role of company size, industry and location. Journal of Small Business Enterprises Development, 12(2), 244-258.

Carayannis, EG, \& Von Zedtwitz, M. (2005). Architecting gloCal (global-local), real-virtual incubator networks (G-RVINs) as catalysts and accelerators of entrepreneurship in transitioning and developing economies: lessons learned and best practices from current development and business incubation practices. Technovation, 25(2), 95-110.

Cooke, P, Kaufmann, D, Levin, C, \& Wilson, R. (2006). The biosciences knowledge value chain and comparative incubation models. Journal of Technology Transfer, 31, 115-129.

CSES. (2002). Benchmarking of business incubators, rapport final. Bruxelles: Commission Européenne.

Ernst \& Young. (2003). Evaluation à mi-parcours des incubateurs d'entreprises innovantes liés à la recherche publique, rapport de synthèse final. Paris: Ministère de la Recherche.

Grimaldi, R, \& Grandi, A. (2005). Business incubators and new venture creation: an assessment of incubating models. Technovation, 25(2), 111-121.

Hackett, SM, \& Dilts, DM. (2004). A systematic review of business incubation research. Journal of Technology Transfer, 29, 55-82. Mahé de Boislandelle, H. (1993). Gérer les hommes de la jeune entreprise. Paris: Chotard Editeurs.

Messeghem, K, \& Pierson, F. (2003). Structure et pratique de GRH dans les moyennes entreprises. Economies et Societes, 13, 845-865.

Pettigrew, A. (1987). Context and action in the transformation of the firm. Journal of Management Studies, 24(6), 649-670.

Pichault, F, \& Nizet, J. (2000). Les pratiques de gestion des ressources humaines. Paris: Editions du Seuil.

von Zedtwitz, M. (2003). Classification and management of incubators: aligning strategic objectives and competitive scope for new business facilitation. International Journal of Innovation Management, 3(1/2), 176-196.

von Zedtwitz, M, \& Grimaldi, R. (2006). Are service profiles incubator-specific? Results from an empirical investigation in Italy. Journal of Technology Transfer, 31(4), 459-468.

10.1186/2192-5372-3-3

Cite this article as: Bakkali et al:: Toward a typology of incubators based on HRM. Journal of Innovation and Entrepreneurship 2014, 3:3 